\title{
CONTEMPORARY ECONOMIC DETERMINANTS FOR THE CHOICE OF THE LEADERS OF THE BRAZILIAN PUBLIC ADMINISTRATION ${ }^{1}$
}

\author{
Jonatas Dutra Sallaberry ${ }^{2}$ \\ Leonardo Flach $^{3}$
}

http://dx.doi.org/10.1590/1413-2311.242.89611

\begin{abstract}
The Brazilian national elections of 2018 constitute a milestone as the first election in the history of the Brazilian public administration in which there was restriction of donations of legal entities. This paper aims to analyze the influence of economic power on electoral choice, for which a prediction model based on financial and political-ideological variables is proposed, identifying if the odds ratio is increased for candidates with greater economicfinancial disposition. We proposed a logistic regression model and estimated the probability of success in the electoral campaign and its relationship with the variables. We collected the data from the open base of the Brazilian Electoral Justice, totaling a universe of 46,867 valid applications in 2018 and 2014. The results show a new logistic regression model, in which it was verified that the candidate's condition to seek his re-election is the factor of greater relationship with the ratio of chances of electoral success, increasing by 6 times the chances of a candidate succeeding in the election. Economic-financial variables of interest confirmed the influence that economic power has on the election process in the same way as the

\footnotetext{
${ }^{1}$ Recebido em 15/01/2019; aprovado em 22/07/2019.

${ }^{2}$ Ministério Público Federal e Universidade Federal de Santa Catarina UFSC); Florianópolis -SC (Brasil) http://orcid.org/0000-0001-7492-727X. E-mail: jonatas.sallaberry@hotmail.com.

${ }^{3}$ Universidade Federal de Santa Catarina (UFSC); Florianópolis - SC (Brasil) - http://orcid.org/0000-00024316-0704. E-mail: leonardo.flach@gmail.com.
} 
dominant ideology in central government, leaving the results of financing by legal entities conflicting.

Keywords: Public Administration. Democracy. Elections. Logistic Regression.

\title{
DETERMINANTES ECONOMICOS CONTEMPORÁNEOS PARA LA ELECCIÓN DE LOS LIDERES DE LA ADMINISTRACIÓN PÚBLICA BRASILEÑA
}

\begin{abstract}
RESUMEN
Las elecciones nacionales brasileñas de 2018 consisten en un marco como la primera elección en la historia de la administración pública brasileña en que hubo restricción de donaciones de personas jurídicas. Este artículo tiene como objetivo analizar la influencia del poder económico en la elección, para lo cual se propone un modelo de previsión basado en variables financieras y político-ideológicas, identificando si la razón de oportunidad es aumentada para candidatos con mayor disposición económico-financiera. Propusimos un modelo de regresión logística y estimamos la probabilidad de éxito en la campaña electoral y su relación con las variables. Recolectamos los datos de la base abierta de la Justicia Electoral brasileña, totalizando un universo de 46.867 candidaturas válidas en 2018 y 2014. Los resultados evidencian un nuevo modelo de regresión logística, en el cual se constató que la condición del candidato para buscar su reelección es el factor de mayor relación con la razón de posibilidades de éxito electoral, ampliando en 6 veces las posibilidades de que un candidato tenga éxito en elecciones. Las variables económico-financieras de interés confirmaron la influencia que el poder económico tiene en el proceso de elección electoral de la misma forma como la ideología dominante en el gobierno central, quedando en conflicto los resultados del financiamiento por personas jurídicas.
\end{abstract}

Palabras clave: Administración Pública. Democracia. Elecciones. Regresión Logística.

\section{DETERMINANTES ECONÔMICOS CONTEMPORÂNEOS PARA ESCOLHA DOS LÍDERES DA ADMINISTRAÇÃO PÚBLICA BRASILEIRA}




\section{RESUMO}

As eleições nacionais brasileiras de 2018 consistem em um marco como a primeira vez na história da administração pública brasileira em que houve restrição de doações de pessoas jurídicas. Este artigo tem como objetivo analisar a influência do poder econômico na escolha eleitoral, para o qual é proposto um modelo de previsão baseado em variáveis financeiras e político-ideológicas, identificando se a razão de chance é aumentada para candidatos com maior disposição econômico-financeiras. Propusemos um modelo de regressão logística e estimamos a probabilidade de sucesso na campanha eleitoral e sua relação com as variáveis. Coletamos os dados da base aberta da Justiça Eleitoral brasileira, totalizando um universo de 46.867 candidaturas válidas em 2018 e 2014. Os resultados evidenciam um novo modelo de regressão logística, no qual constatou-se que a condição do candidato buscar sua reeleição é o fator de maior relação com a razão de chances de sucesso eleitoral, ampliando em 6 vezes as chances de um candidato ter sucesso no pleito. As variáveis econômico-financeiras de interesse confirmaram a influência que o poder-econômico tem no processo de escolha eleitoral, da mesma forma como a ideologia dominante no governo central, restando conflitantes os resultados do financiamento por pessoas jurídicas.

Palavras-chave: Administração Pública. Democracia. Eleições. Regressão Logística.

\section{INTRODUCTION}

The Brazilian political scene has provided improper situations at least of its members, since conflicting relations with ethics, to the appropriation of public property by its agents. The problems highlighted come from management actions and their effects, and the electoral process.

The main discussions in regard to improper practices in election campaigns are vote buying, selling spaces, misuse of public administration and the use of illicit funds (slush), due to behaviors such as political corruption, influence peddling and abuse of economic power (RODRIGUES; SALLABERRY, 2013). The ownership, control and benefits of the assets do not represent illegal activity, but may signal evidence of other crimes, such as embezzlement, concealment of assets, corruption, slush, among other offenses identified. 
Despite any criminal activities, the perception of the influence of economic power in the electoral process is inevitable, whether by ownership of assets that demonstrate professional success and can serve the patronage practices of economic influence, and given the scale of the campaign expense. It is perceived as relevant research on how the election process can be influenced by too much money, or abuse of economic power (ARVATE; BIDERMAN, 2005; AVIS et al., 2018; CAVALCANTE, 2015; CERVI, 2010; HORTA; DUFLOTH; FREITAS, 2016; KLEIN, 2010; MORAES; ANDION; PINHO, 2017; SALLABERRY; RODRIGUES; VENDRUSCOLO, 2014).

The prospect of how voters make their electoral choices is subject of interest of several study areas, political sciences and applied social sciences, such as management, accounting and law (BAINES; EGAN, 2001; BARROS; SAUERBRONN; AYROSA, 2012; O'SHAUGNNESSY, 2001), which has been left in the background in Brazil.

In order to seek to identify the degree of chances that a candidate possessing greater magnitude of goods and expenses, this article aims to propose an electoral prediction model based on financial variables, identifying the odds ratio that is increased to candidates with greater willingness to balance power.

For the present scope, the methodology is quantitative exploratory study, the absence of reference for further deepening of theoretical discussions, utilizing the logistic regression model for prediction of events occurring with binary frequency.

Academic production on voter behavior and political marketing in public administration is limited and therefore there is a lack of possibilities for studies so only for the effort to understand the political and electoral choices already justified (BARROS; SAUERBRONN; AYROSA, 2012). The scope of seeking help with an analytical model that discusses the change in the ratio of electoral chances of success of a candidate with greater financial availability is already contributing to the academic and professional discussions.

From the financial data and personal characteristics of the candidates highlighted the empirical theoretical framework, the expected possibility was built that economic power reflects better election result according to the methodology that can be synthesized in the application of a statistical logistic model. This hypothesis proposed permeates the development of election forecasting model that highlights the resolution of a positive relationship between the availability of funds and some individual characteristics. 


\section{LITERATURE REVIEW}

Grandi, Marins and Falcão (1992) indicate the importance of determining the pattern of behavior of voters as voting decision. For Barros, Sauerbronn and Ayrosa (2012), voting behavior trends could be provided depending on the composition of the socio-cultural characteristics, while Kamakura (2016) comes to applying model of electoral choice to the actual behavior of the voter.

The assumption of accountability and especially the scope of analysis of the statement of assets, the sources of funds and campaign expenses, attract technical and scientific expertise of the accounting science to professional practice and academic with regard to the financial power of the ability to influence the process electoral. Part of the few studies on proxies that influence the decision of the voter based on the assumption that political marketing is a tool used to influence the voter and the political choice is an eminently rational decision in Brazil (BARROS; SAUERBRONN; AYROSA, 2012).

\subsection{ELECTIONS AND THE RELATIONSHIP WITH PULIC ADMINISTRATION}

The trade relations are governed by a market perspective, where the choice is defined by having great influence as the advantage in financial terms. We cannot say that the perception measured in financial terms should not be considered as a determining factor or determined social choices, depending on the agent's rationalization process. The financial aspects perceived by public opinion may impact the choices of voters at election time (CAVALCANTE, 2015; DIAS; NOSSA; MONTE-MOR, 2018), while the financial connections of electoral income and expenses politicians can influence the financial performance of organizations (ZHU; CHUNG, 2014).

In the electoral process, the financial value is employed as a research proxy in the electoral choice process. Research in this line found the influence of expenditures in previous political cycles, investment spending in construction and large projects that generate jobs or visibility, the influence of the increase in the execution of public expenditure and economic growth, the measurement of the cost of the vote, limits campaign spending, influence of political connection with candidates and parties regarding the performance of the donor companies, similarity relation between the characteristics and the demographic and socioeconomic profile, to the application of electoral choice models. The electoral process and finances are inextricably linked. 
The influence of the public policies in the elections is relevant because the opinion of the voter approaching the economic and political sectors, and may reflect the choices of voters at election time (NAKAGUMA; BENDER, 2005). Schuknecht (2000) highlights the effect of the increase of investment projects spending on employment rates, while voters reward governments that promote increases in public investments in the period surrounding the elections (DIAS; NOSSA; MONTE-MOR, 2018).

Rulers direct budget execution for more visible spending the electorate in periods close to the elections (KLEIN; SAKURAI, 2015; SHI; SVENSSON, 2006). The voter considers the previous financial management as a factor for making electoral decision, called economic vote, in which effects of economic growth relates to the proportion of votes obtained (FERNANDES; FERNANDES, 2017).

In contrast, models of political cycles suggest that managing the electoral expenditures serve to signal the administrative competence of the rulers (NAKAGUMA; BENDER, 2010). Authors, otherwise question this relationship seeking empirical different evidences (DRAZEN; ESLAVA, 2005; PELTZMAN, 1992; BRENDER; DRAZEN, 2005), which may even reverse the perception of voters because those measures cause payment deficits and perceived intentional management.

The political connections between companies and elected through electoral donations has been the subject of recent research (CRUZ; PARENTE, 2018; PINHEIRO; DE LUCA; VASCONCELOS, 2016). Other studies have discussed the electoral cash flow for spent on campaign expenses, relating to the cost of the vote (CAZZOLATO; CANDIDO, 2013; SALLABERRY; VENDRUSCOLO; RODRIGUES, 2014).

Voters' choices tend to be rational and seek maximize the usefulness of the vote, reducing their costs and increasing their benefits, before this assumption - voters tend to vote for leaders who best align with your goals and preferences (DOWNS, 1957; NICOLAU, 2006; CAVALCANTE, 2015). Other elements that may influence the choice of the elect are the characteristics and social and economic profile of the elect, whose distributions of the groups reflect the changes in the regional population profile (HORTA; DUFLOTH; FREITAS, 2016).

Initially the research proposal seeks to identify the influence of economic power, which can be perceived by the goods and the expenses of the candidates. In this context, we propose the possibility that candidates with these characteristics indicate more or less suitable candidates, as perception of voters. 
Candidates declare to the Electoral their property during the campaign record, considering that only the assets. The possibility of this variable to have the ability to influence the voter follows the incorporation of the notion of rationality and the availability of significant financial resources may signal some skills (ARVATE; BIDERMAN, 2005). Greater amount of equity may signal the increased financial management capacity which would be assessed by the voter, or you can signal the inability to perception of social problems of less affluent voters groups.

Appropriate spending campaign variable is available in the accounting files, along with details of all expenses, and even recipes. The use of appropriate variable expense arises from the fact that the electoral success stems from voter persuasion on the proposals of the candidates, and it is critical to conduct spending disclosure, without which the proposals would not reach voters. Cervi (2010) points out that the money makes a difference in the election, with positive expectations in line with revenues, given that tend to be the same because of that spending depends on the financing; that even can influence unlawfully by vote buying (MORAES; ANDION; PINHEIRO, 2017). Arvate, Avelino and Lucinda (2008), that Brazilian voters have a preference for higher levels of spending

Sallaberry, Rodrigues and Vendruscolo (2014) identified a positive relationship between the higher cost of the vote and the electoral success, not based on economic and geographic reasons, and highlight the reasonableness of the most significant positions campaigns require greater investment in campaigns.

The imposing campaign spending limits tend to become more equitable political competition by attracting the largest number of candidates (AVIS et al., 2018). The 2018 Brazilian elections for president, governor, federal deputy and state deputy, was the first election with restriction on donations from legal entities.

In addition to analyzing the proposal of the influence of economic power in the electoral success, other features can naturally assist the decision-making process of the election. For example, Klein (2010) relate that linking same party of the president or governor can increase the chances of success. Horta, Dufloth and Freitas (2016) emphasize that social and economic characteristics may reflect the appreciation of the voter.

In the scope of this research has been optimized analysis with the other variables provided by the Electoral Court of each candidate, including the re-election conditions, color / race, nationality, gender, marital status, level of education and age. In choosing candidates the most important factor for voters, the focus is the candidate of the person (NICOLAU, 2006). 
The variable reelection stems from those candidates who already occupy the desired position, which is assigned a positive influence given the increased availability of funds to invest in the campaign and evidence that the election campaign has endogenous inputs of candidates (AVIS et al., 2018). In addition, the condition of already ruling allows the voter to evaluate their performance, which would be decisive (COELHO, 2004), skewed considering the factors presented in the research on the relationship of the political cycle and the level of costs. This condition would have a positive impact on the electoral success (CAVALCANTE, 2015; KLEIN; SAKURAI, 2015).

The variable race has been considered by Avis et al. (2018) and distinguished by Barros, Sauerbronn and Ayrosa (2012). During the campaign registration applicants declare themselves as yellows, whites, Indians, blacks and browns, which can be perceived by voters as influence factor of their choice, either by proximity of ethnic voter group or improper application of prejudice on the ethnic groups of candidates capacity traditionally subjugated by prejudice.

The variable nationality highlighted by Barros, Sauerbronn and Ayrosa (2012) can also be an element of the voter's choice process. Much in line with previous variable, race, also allows the voter to recognize how similar or reject a nationality candidate. For registration, applicants declare themselves as Brazilian born, naturalized Portuguese or foreigners, though the vast majority of candidates universe are native Brazilians, which can transfer the rationalization of choice for variable race.

The variable gender has been considered by Horta, Dufloth and Freitas (2016), Avis, et al. (2018) as a variable of electoral choice process. This variable carries elements of appreciation or rejection based on similarity or voter and candidate relationship of group differences. Horta, Dufloth and Freitas (2016) point out that women are still underrepresented in boards, which may have roots in the historic Brazilian social inequality.

Although the group of voters women in Brazil has exceeded the number of men, Horta, Dufloth and Freitas (2016) found that the representation of women increased from $10.1 \%$ of those elected to only $13.0 \%$ between 1998 and 2010 . In because of these results, the expectation is that the females display decrease the rate of electoral chances of success for the female candidate.

The variable marital status although it was not identified as grounded element in previous studies, it is variable candidate individual features available on the Electoral Court data file and, because it is empirical research, there is no reason to reject the check on a possible relationship. Empirically, the same as in job interviews, individuals with family tend 
to have greater responsibility and emotional stability that can guarantee the commitment of elected with the civil service, but also higher load personal commitments that can compromise the performance of functions.

The variable level of education has already been considered by Horta, Dufloth and Freitas (2016), Avis et al. (2018). According to Horta, Dufloth and Freitas (2016), Brazilian voters have preference for candidates who have a university degree, reaching a $70.1 \%$ of the universe elected in 2010. Other studies relate the level of education of voters for re-election (VICENTE; NASCIMENTO, 2012; ARAUJO JUNIOR; CANÇADO; SHIKIDA, 2005), which in part shows the trend of professionalization in political representation careers.

The variable age has already been considered by Horta, Dufloth and Freitas (2016), Avis et al. (2018), which may show the aging of political as well as the general population, reaching the next average age of 48 years in elections 2010. The expectation is that the higher the age, the more experience and knowledge, which can influence the management capacity of the candidate elected.

\subsection{RESEARCH HYPOTHESES}

The present research established three axes of hypotheses to test empirically based on the literature, among them the hypothesis of economic power of interest of researchers, of party or ideological politics, and of control.

\subsubsection{Economic power in the application}

The economic power of the candidates in the empirical proposal is represented by the equity declared by the candidate, in the amount of the expenses used during the campaign, and transversally a variable of funding of business financing. In electoral choice, the most important factor for voters is the candidate's person (NICOLAU, 2006). The availability of significant financial resources may signal some competencies (ARVATE and BIDERMAN, 2005), either by managing personal assets or by raising funds for projects in the case of a campaign.

Money in different forms influences the outcome of the lawsuit (ARVATE; AVELINO; LUCINDA， 2008; CERVI， 2010; SALLABERRY， RODRIGUES; VENDRUSCOLO, 2014). It is necessary to consider a greater availability of resources when it was allowed the donation of resources by companies, which likewise reflects in the 
economic power. The 2018 election was the first national level with restriction on donations of legal entities, and in the present research is operationalized with an indicative variable of private electoral financing, of the 2014 electoral campaign, when the source was allowed, in this case working similar to a moderation in campaign spending, however isolated for empirical testing. Thus, the hypotheses of economic power are as follows:

$\mathrm{H}_{1 \mathrm{a}}$ : the candidate's greater assets influence the electoral success;

$\mathrm{H}_{1 \mathrm{~b}}$ : the largest investment in the candidate's electoral campaign influences electoral success;

$\mathrm{H}_{1 c}$ : private financing influences electoral success;

\subsubsection{Partitional or ideological policy}

The aspects of partisan or ideological politics are those reflected from the connection of party-political networks or ideas, which has electoral appreciation. These questions are operationalized by reelection variables, parties, dominant ideologies in the national scenario, unit of the federation and geographic region.

The reelection of those candidates who already hold the position they hold has a positive influence (STOKES, 1996; AVIS, FINAN, VARJÃO, 2018), and the status of governor allows the voter to evaluate their performance, which would be decisive (COELHO, 2004, CAVALCANTE, 2015; KLEIN; SAKURAI, 2015). Empirical fragments indicate the possibility of the politician transferring political capital to the other candidates of the same party, including capturing eventual decentralization of resources to the linked federated units, which can be perceived by the variable Party.

Klein (2010) and Cavalcante (2015) relate the linkage to the same party of the political leader can increase the chances of success, including allowing to infer that this appreciation is captured by the candidates of parties in the form of a dominant ideology. Horta, Dufloth and Freitas (2016) highlight social and economic characteristics that could be perceived by demographic variables. Thus, the hypotheses formulated test:

$\mathrm{H}_{2 \mathrm{a}}$ : the elected status influences electoral success;

$\mathrm{H}_{2 \mathrm{~b}}$ : the candidate's party influences electoral success;

$\mathrm{H}_{2 \mathrm{c}}$ : dominant ideology influences electoral success;

$\mathrm{H}_{2 \mathrm{~d}}$ : the geographic region influences electoral success; 
Other control variables are inserted into the model to capture specific effects, usually already known. In the present model were inserted variables of color or race, nationality, gender, marital status, educational level and age.

\section{METHOD}

The method in this study was an exploratory study on subject hitherto unexplored by academic literature, developed in order to provide a general and approximate view of certain subject in a methodical and organized in phases using a set of intellectual and technical procedures of which depends on scientific research (GIL, 1999). From the analysis of database records, the exploratory study provides further information on the matter to be investigated, facilitates delimitation of the subject, guides the setting of objectives and the definition of assumptions, in addition to finding new approaches to the subject; this results may form the basis for further investigations (WALLIMAN, 2001).

In 2018, 29,146 candidatures were registered with the electoral court. Due to the limited characteristics of the electoral success variable, it has been simplified into a dichotomy of success or failure, since electoral success categories are confused to depend on other electoral results, such as electoral quotient, candidates with high appreciation, votes in caption, availability of electoral background, and party propaganda hours, in general, characteristics captured by other variables of the proposed empirical model.

The political or ideological variables presented a greater difference, and the reelection condition presents its own dichotomous characteristic, the dominant ideologies in the national scenario were simplified in dichotomic with occurrence for the candidates of parties of the electoral coalition winning the electoral coalition. The geographical region standardized by the traditional geographic categories and the parties analyzed categorically and separately, due to the number of 41 parties represented.

Control variables were simplified into dichotomous variables ( 0 and 1$)$, from clusters with common social characteristics, such as the variables race, nationality, gender, marital status, education level and candidate, and complementarily analyzed in an aggregated way to discuss the results.

Based on the concepts described above variables (see Table 1) were built based on the available data of the population, after procedures described in the methodology, the applicants reached 25,376 in the election 2018, and 21,514 in the 2018. The dichotomous 
variables have a default value of zero, and the existence of the characteristic displays the value 1 .

Table 1 - Variables Description

\begin{tabular}{|c|c|c|c|}
\hline Variable & Feature / condition $(0)$ & Feature / condition (1) & Multiple Categories \\
\hline Success & $\begin{array}{l}\text { - Elected } \\
\text { - Elected for average } \\
\text { - Elected for QP } \\
\text { - 2nd. Shift }\end{array}$ & $\begin{array}{l}\text { - Alternate } \\
\text { - Not Elected }\end{array}$ & 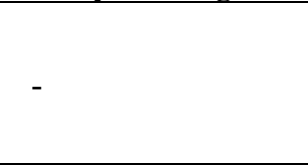 \\
\hline Assets & \multirow{2}{*}{\multicolumn{3}{|c|}{$\begin{array}{l}\text { - natural logarithm of the sum of the applicant's assets } \\
\text { - Natural logarithm of the value of the appropriate campaign expenses in providing the } \\
\text { applicant's accounts }\end{array}$}} \\
\hline Expense & & & \\
\hline $\begin{array}{c}\text { Business } \\
\text { Financing }\end{array}$ & 2018 & 2014 & - \\
\hline Re-election & - Not & - Yes & - \\
\hline $\begin{array}{l}\text { Party } \\
\text { Ideology }\end{array}$ & Outros & $\begin{array}{l}\text { 2014: PT, PMDB, PDT, PC } \\
\text { do B, PP, PR, PSD, PROS and } \\
\text { PRB } \\
\text { 2018: PSL, PRTB }\end{array}$ & - \\
\hline Matches & - & - & All 41 matches \\
\hline Region & - & - & $\begin{array}{l}\mathrm{CO}, \mathrm{N}, \mathrm{NE}, \mathrm{S} \text { and } \\
\mathrm{SE}\end{array}$ \\
\hline Race & $\begin{array}{l}\text { - Yellow } \\
\text { - White }\end{array}$ & $\begin{array}{l}\text { - Indigenous } \\
\text { - Brown } \\
\text { - Black }\end{array}$ & 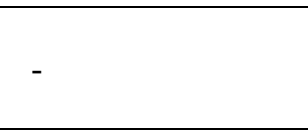 \\
\hline Nationality & - Native Brasilian & $\begin{array}{l}\text { - Naturalized Brazilian } \\
\text { - Portuguese } \\
\text { - Foreign }\end{array}$ & - \\
\hline Gender & - Male & - Female & - \\
\hline Marital status & $\begin{array}{l}\text { - Not married } \\
\text { - Widowed } \\
\text { - Separate } \\
\text { - Divorced }\end{array}$ & - Married & - \\
\hline Literacy & $\begin{array}{l}\text { - Read and write } \\
\text { - Elementary School } \\
\text { Incomplete } \\
\text { - Elementary School Complete } \\
\text { - Incomplete high school } \\
\text { - Complete high school } \\
\text { - Age of Value in years to the da }\end{array}$ & $\begin{array}{l}\text { - Higher Education } \\
\text { Incomplete } \\
\text { - Higher Education } \\
\text { Complete } \\
\text { te of possession }\end{array}$ & - \\
\hline
\end{tabular}
Source: elaborated by the authors.

Data collected for the study were taken from the open database of Electoral Justice ${ }^{4}$ in January 2019, the candidates files, assets and accountability. The selected data were intentionally election campaign 2018, whose claims are national and state, showing the result of the latest social behavior. In addition, 2014 candidates were included for the incorporation of financing variables by companies, when it was legally permitted.

${ }^{4}$ Available at http://www.tse.jus.br/. 
By selecting only valid applications, was excluded from the candidates with the Application Registration situation unfit, and situation Null. The uniqueness of the election, the application records for president and vice corresponding to were excluded. In addition, they excluded records of candidates for deputy governors and senators of deputies for not having campaign expenses and mainly do not reflect the application object, and already included in the sample with the main applicant data, leaving the universe of 25,376 candidates from the 2018 election, and 21,491 applications valid in 2014.

The choice of the logistic regression analysis is justified by the need to estimate the probability of success in the election campaign, and their relationship due to the candidate's profile (FAVERO et al., 2014). In logistic regression, the probability of an event can be estimated directly. In this case, where the dependent variable Y take only two possible outcomes (1-success or failure- 0 ), the success corresponds to electoral victory, regardless of claimed position as the failure is not being elected. By discretion, it was considered successful (1) the candidate's result to reach the second round.

The absence of multicollinearity assumption can be tested after a traditional regression of these data through the inflation factor of variance test (VIF - variance inflation factor) (FIELD, 2009). The VIF statistical parameter has the value 10, above this value it is indicated as highly collinear; while its inverse, or TOL statistic parameter whose value is 1 .

Through Stata statistical software, employed in the statistical analysis, we found that the calculated values VIF present between 1.00 and 1.49, less than 10 (Mean 1:19). Therefore, acceptable. Its inverse, the TOL presents statistical values greater than 0.72 , close to 1 . It is therefore acceptable value; values close to 0 would indicate multicollinearity. From the results obtained, it is identified that the premise of no multicolinearity is present, which allows an adequate statistical calculation.

Logistic regression is a specialized form of regression that is formulated to predict and explain a binary categorical variable, in this case, not metrics by encoding means from a set of explanatory variables (FIELD, 2009; HAIR JR et al., 2009; FÁVERO et al., 2014).

The dependent variable has only binary values 0 or 1 , and the predicted value is limited to be within this range. To define this relationship limited between 0 and 1 , using logistic regression to logistic curve representing the relationship between independent and dependent variables. Very low levels of the independent variable, the probability approaches 0 without reaching such value. Likewise, when increasing, the predicted values grow to the top of the curve so that increasing the level of the independent variable probability threshold 
will approach 1 (HAIR JR et al., 2009). The logistic curve is a probabilistic behavior in the shape of letter S (HOSNER; LEMESHOW, 1989).

A binary logistic regression does not estimate values for the dependent variable, but the probability of occurrence of the event in each observation, based on the explanatory variables. According to Fávero and Belfiore (2017), logistic regression is defined as a general expression of the probability of dichotomy for observation, as follows.

$$
p_{i}=\frac{1}{1+e^{-\left(\alpha+\beta_{1} \cdot X_{1 i}+\beta_{2} \cdot X_{2 i}+\beta_{3} \cdot X_{3 i}+\ldots+\beta_{k} \cdot X_{k i}\right)}}(1)
$$

Logistic regression for the binary nature of the dependent variable ( 0 or 1$)$ has properties that violate the assumptions of a traditional regression. Among these assumptions dismissed, or not observed, they are normal. After all, the error term of a discrete variable follows a binomial distribution, the variance of homoscedasticity, a dichotomous variable which is not constant, creating cases of heteroskedasticity (HAIR JR. et al, 2009).

The non-linear nature of the logistic transformation requires the maximum likelihood estimation method is used iteratively to finding the most probable estimates of the coefficients. In place to minimize the squared deviations (least squares), logistic regression maximizes the probability that an event occurs (HAIR JR. et al, 2009).

\section{DATA ANALYSIS AND DISCUSSION}

The analysis consisted of election data descriptive analysis of the data synthesis where the quantities medium is verified, and limits events. Then it was used to analyze the inferential results by applying logistic regression theoretical and empirical data model proposed in this research as well as the qualitative fit of the model and statistical tests to stick reach constructed perception of the influence the financial capacity in the election result.

\subsection{DESCRIPTIVE ANALYSIS}

The descriptive analysis of the data allows us to highlight some features that are dominant in the universe of candidates for political office, such as the Brazilian Nationality predominant in $99.54 \%$ of the candidates, in addition to not post holders for $94.85 \%$ of the candidates are 'not incumbents', and the remaining 1306 candidates are running for the same office. 
Other individual characteristics also predominate in the universe, and individually account for most, as of $69.04 \%$ Male, Married in $54.72 \%$ of the candidates, in $52.67 \%$ White, and full academic level or training in 14797 cases or $58.31 \%$ (see Table 2). The focus of the analysis is the 2018 data for a more updated analysis, taking 2014 as a benchmark.

Table 2 - Descriptive analysis

\begin{tabular}{lccrc}
\hline \multicolumn{1}{c}{ Nationality } & Cod & Qtd18 & Pcp18 & Pcp14 \\
\hline Brazilian & 0 & 25250 & 99.51 & $99.54 \%$ \\
Naturalized & 1 & 113 & 0.45 & $0.45 \%$ \\
Portuguese & 1 & 6 & 0.02 & $0.00 \%$ \\
Foreign & 1 & 6 & 0.02 & $0.01 \%$ \\
Total & & 25375 & & $\mathbf{1 0 0 \%}$
\end{tabular}

\begin{tabular}{lcrrr}
\hline \multicolumn{1}{c}{ Marital status } & Cod & Qtd18 & Pcp18 & Pcp14 \\
\hline Not married & 0 & 7974 & 31.42 & $29.94 \%$ \\
Widower & 0 & 399 & 1.57 & $1.81 \%$ \\
Separate & 0 & 281 & 1.11 & $1.80 \%$ \\
Divorced & 0 & 2836 & 11.18 & $10.44 \%$ \\
Married & 1 & 13885 & 54.72 & $56.01 \%$ \\
Total & & 25375 & & $\mathbf{1 0 0 \%}$ \\
\hline
\end{tabular}

\begin{tabular}{lcccc}
\hline \multicolumn{1}{c}{ Sex } & Cod & Qtd18 & Pcp18 & Pcp14 \\
\hline Male & 0 & 17518 & 69.04 & $71.03 \%$ \\
Female & 1 & 7857 & 30.96 & $28.97 \%$ \\
Total & & 25375 & & $\mathbf{1 0 0 \%}$
\end{tabular}

\begin{tabular}{lcrrr}
\hline \multicolumn{1}{c}{ Instruction } & Cod & Qtd18 & Pcp18 & Pcp14 \\
\hline Read and write & 0 & 227 & 0.89 & $0.96 \%$ \\
Element. School inc & 0 & 784 & 3.09 & $3.26 \%$ \\
Element. School & 0 & 1442 & 5.68 & $7.19 \%$ \\
comp & 0 & 722 & 2.85 & $3.01 \%$ \\
High School inc & 0 & 7403 & 29.17 & $29.24 \%$ \\
High School ens & 0 & 2312 & 9.11 & $9.71 \%$ \\
Pos-school inc & 1 & 12485 & 49.2 & $46.63 \%$ \\
Pos-school comp & 1 & & \\
Total & & 25375 & & $\mathbf{1 0 0 \%}$ \\
\hline
\end{tabular}

\begin{tabular}{|c|c|c|c|c|}
\hline Race & Cod & Qtd18 & Pcp18 & Pcp14 \\
\hline Yellow & 0 & 148 & 0.58 & $0.47 \%$ \\
\hline White & 0 & 13366 & 52.67 & $55.57 \%$ \\
\hline Indigenous & 1 & 112 & 0.44 & $0.34 \%$ \\
\hline Brown & 1 & 9003 & 35.48 & $34.59 \%$ \\
\hline Black & 1 & 2746 & 10.82 & $9.04 \%$ \\
\hline Total & & 25375 & & $100 \%$ \\
\hline Re-election & Cod & Qtd18 & Pcp18 & Pcp14 \\
\hline Not & 0 & 24069 & 94.85 & \\
\hline Yes & 1 & 1306 & 5.15 & \\
\hline Total & & 25375 & & $100 \%$ \\
\hline
\end{tabular}

Source: elaborated by the authors.

Other information of the candidates are also provided by the electoral authority, among them, their ages, their property and the value indicated as appropriate expense or revenue collected during the campaign. The age of the candidates is provided in whole numbers by the value of age at the time of the can, if elected. The universe of candidates has on average 47.6 years, with the youngest aged 20 and the oldest 94 years old. From a cutout> 500 for year candidates, it is clear that the high concentration of candidate is between 33 and 58 years of age, as shown in Figure 1. 


\section{Figure 1 - Normal distribution of candidates age 2018 Election}

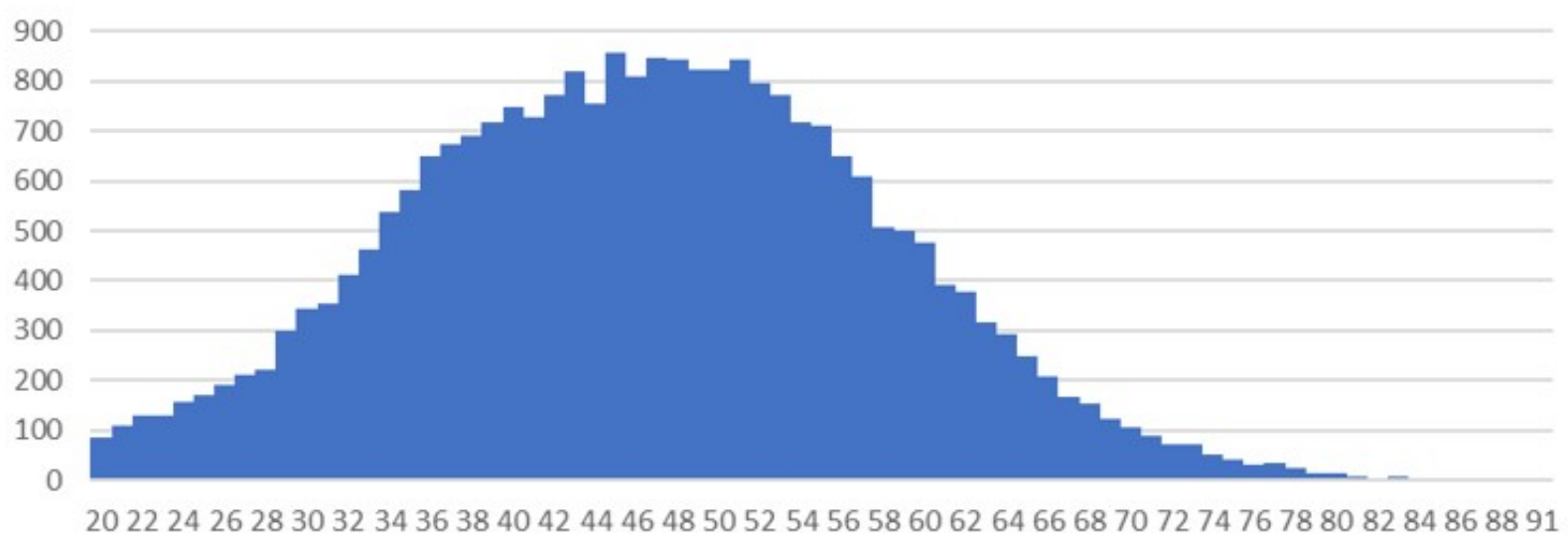

Source: elaborated by the authors.

Among the candidates, 15,841 candidates have declared assets $(62.43 \%)$, totaling BRL 14.76 billion, resulting in an average declared assets of BRL 932,023.29. Correcting the values declared by the three candidates with the highest value from the breakdown of assets, the largest of a candidate equity value reaches BRL 600 million, ten candidates declare more than BRL 100 million. In total universe of candidates the value reaches an average of BRL 520,000 , and we must consider that the goods declared are subject to inconsistencies, mainly by default and disclosure for historical value (SALLABERRY; CODESSO; FLACH, 2019).

The greatest asset is realized for those candidates for governorships and senator, respectively, followed by the heritage of candidates for deputies of positions and state and district deputies, as the table below.

Table 3 - Assets of the candidates 2018.

\begin{tabular}{lcrrr}
\hline \multicolumn{1}{c}{ Office } & QTY & \multicolumn{1}{c}{ Assets } \\
Average & \multicolumn{1}{c}{ Bigger } & \multicolumn{1}{c}{ Sum } \\
\hline Deputy district & 922 & $340,262.94$ & $33,838,344.74$ & $313,722,432.26$ \\
Deputy state & 16232 & $392,325.71$ & $255,665,376.25$ & $6,368,230,872.11$ \\
Congressman & 7717 & $742,240.91$ & $600,000,000.00$ & $5,727,873,064.30$ \\
Senator & 301 & $3,582,980.38$ & $239,709,825.12$ & $1,078,477,094.50$ \\
Governor & 203 & $6,285,110.88$ & $189,859,904.76$ & $1,275,877,509.34$ \\
General results & $\mathbf{2 5 3 7 5}$ & $\mathbf{5 8 1 , 8 3 9 . 6 4}$ & $\mathbf{6 0 0 , 0 0 0 , 0 0 0 . 0 0}$ & $\mathbf{1 4 , 7 6 4 , 1 8 0 , 9 7 2 . 5 1}$ \\
\hline Source:
\end{tabular}

Source: elaborated by the authors.

Campaign spending, considering the appropriate expenditure by candidates, reached BRL 2.99 billion, spent by 17647 candidates, because that 7728 candidates do not declare the realization of campaign expenses. Other 1627 candidates declared having made 
expenditures of up to BRL 1,000.00. Considering all the candidates, the average is BRL 118,000 in expenses accrued by each candidate. The parties perform other campaign spending, in general, to promote or make more effective the party's image, but because they are not allocated to the applicants, no longer considered.

Just as the amount of declared assets, the volume of campaign spending is higher for candidates for governorships, senator, federal, state and district deputies, respectively.

Table 4 - The volume of campaign spending 2018

\begin{tabular}{lcrrr}
\hline \multirow{1}{*}{ Office } & \multirow{2}{*}{ QTY } & \multicolumn{3}{c}{ Spending contractor } \\
& & \multicolumn{1}{c}{ Average } & \multicolumn{1}{c}{ Bigger } & \multicolumn{1}{c}{ Sum } \\
\hline Deputy district & 922 & 31135.65 & $959,268.13$ & $28,707,072.83$ \\
Deputy state & 16232 & 51835.56 & $1,128,164.23$ & $841,394,853.69$ \\
Congressman & 7717 & $162,984.39$ & $2,591,858.00$ & $1,257,750,568.21$ \\
Senator & 301 & $890,032.10$ & $5,322,773.62$ & $267,899,662.92$ \\
Governor & 203 & $2,949,420.60$ & $22,135,193.23$ & $598,732,382.20$ \\
General results & $\mathbf{2 5 3 7 5}$ & $\mathbf{1 1 8 , 0 0 9 . 2 4}$ & $\mathbf{2 2 , 1 3 5 , 1 9 3 . 2 3}$ & $\mathbf{2 , 9 9 4 , 4 8 4 , 5 3 9 . 8 5}$ \\
\hline Source: elaborated by the authors. & & &
\end{tabular}

The 25375 candidates of the universe of candidates with characteristics analysis disputed 1677 vacancies in various positions at issue, which represents only $6.6 \%$ of applications would succeed in the election.

Table 5 - Elected and not elected candidates 2018

\begin{tabular}{ccccccc}
\hline Result & Elected & 2nd round & Elected in average & Elected in QP & Alternate & Not elected \\
\hline Deputy district & & & 13 & 11 & 734 & 164 \\
Deputy state & & & 159 & 876 & 13308 & 1889 \\
Congressman & & & 126 & 387 & 4606 & 2598 \\
Governor & 27 & 26 & & & & 150 \\
Senator & 52 & & & & & 249 \\
General results & $\mathbf{7 9}$ & $\mathbf{2 6}$ & $\mathbf{2 9 8}$ & $\mathbf{1 2 7 4}$ & $\mathbf{1 8 6 4 8}$ & $\mathbf{5 0 5 0}$ \\
\hline
\end{tabular}

Source: elaborated by the authors.

The tabulation of descriptive results shows that both the applicant's goods and the expense contracted by the candidate during the campaign are higher in situations where the candidate was successful in the election campaign, as shown in Table 6. 
Table 6 - Campaign expenditures of the candidates 2018

\begin{tabular}{lcccc}
\hline \multirow{2}{*}{ Office } & \multicolumn{2}{c}{ Real media } & \multicolumn{2}{c}{ Average expenditure } \\
& Failure & Success & Failure & Success \\
\hline Deputy district & $282,418.30$ & $2,504,616.47$ & 25547.07 & $240,241.65$ \\
Deputy state & $323,753.40$ & $1,399,179.23$ & 34328.48 & $308,893.71$ \\
Congressman & $643,715.15$ & $2,125,826.70$ & 97548.69 & $1,081,890.49$ \\
Senator & $2,243,201.37$ & $9,998,460.63$ & $719,555.91$ & $1,706,350.81$ \\
Governor & $2,471,358.65$ & $17,078,749.28$ & $1,941,936.33$ & $5,800,791.19$ \\
Total result & $\mathbf{4 5 3 , 2 1 4 . 4 9}$ & $\mathbf{2 , 3 9 9 , 4 6 5 . 7 5}$ & $\mathbf{7 2 4 8 8 . 4 7}$ & $\mathbf{7 6 1 , 2 7 1 . 7 9}$ \\
\hline Source: elaborated by the authors. & & &
\end{tabular}

Sallaberry, Rodrigues and Vendruscolo (2014) found that in some cases the resources invested in campaign not based on economic and geographic reasons. In this case, the descriptive title, you can see with reasonable logic that campaigns to more important positions require greater investment in the campaigns, possibly to publicize their proposals. Candidates for District Deputy positions have lower average amounts spent than the analogous office of State Representative, and the geographical extent is also lower in the Federal District.

The ownership of declared goods also shows indicative relationship with the election result given that the largest magnitude of property values remains among those nominated and who participated in the second round.

\subsection{LOGISTIC REGRESSION ANALYSIS}

From the descriptive elements of the candidates who have obtained electoral success have higher asset availability in goods and performed more value on campaign spending, built up the expected possibility that economic power, based on higher values of assets and equity reflect better election result. This hypothesis proposed permeates the development of the election forecasting model. Because of the availability of characteristics of candidate data, we chose to include other qualitative and quantitative variables to try to expand the explanatory power of the model, such as marital status, sex, race, education, nationality, age and re-condition.

Because of the magnitude of the assets and expenditure values, it was decided to perform the logarithmic transformation of the respective values and provide better fit. Adicionando os dados da eleição de 2014 (see Table 7), a apresentamos os resultados das características descritivas. 
Table 7 - Descriptive statistics - 2014 and 2018

\begin{tabular}{lcccrrrc}
\hline \multicolumn{1}{c}{ Variable } & Obs & Mean & Std. Dev & Min & Max & 0-insuc & 1-suc \\
\hline Resy & 46787 & .071366 & .2574379 & 0 & 1 & 43.448 & 3.339 \\
LogAssets & 28930 & 5.24430 & .835064 & -2 & 9.079 .907 & 28.930 & \\
LogExp & 36355 & 4.21476 & .9851244 & -2 & 7.717 .431 & 36.355 & \\
FPy & 46787 & .459828 & .498389 & 0 & 1 & 25.273 & 21.514 \\
Rey & 46787 & .048175 & .2141398 & 0 & 1 & 44.533 & 2.254 \\
Ideoy & 46787 & .314403 & .4642829 & 0 & 1 & 32.077 & 14.710 \\
CRY & 46787 & .454784 & .4979567 & 0 & 1 & 25.509 & 21.278 \\
Ny & 46787 & .004787 & .0690278 & 0 & 1 & 46.563 & 224 \\
Ecy & 46787 & .553679 & .4971155 & 0 & 1 & 20.882 & 25.905 \\
GIy & 46787 & .574839 & .4943727 & 0 & 1 & 32.735 & 14.052 \\
Age & 46787 & 4.73928 & 1.129 .671 & 20 & 94 & & \\
\hline
\end{tabular}

Source: elaborated by the authors.

Employee in STATA software in the analysis we use the logit command followed by the dependent variable and the independent variables. To optimize the process of estimating the regression model with all variables followed the exclusion of non-significant variables is indicated stepwise procedure (FÁVERO; BELFIORE, 2017). This stepwise statistics (step by step) has better power indicator predictive model from the last stage (FIELD, 2009). The same logarithm values of the expenditure and the resulting goods previously at zero were disregarded from the regression, due to the potential error of information.

Before analyzing the data you need to check the fit of the model, which can be observed in the first part of the outputs. Initially, the maximum values of the log-likelihood function for the complete model and the null model after interaction is $-5339,99$. The ratio test of likelihood (LR test) uses a statistic with chi-square distribution to analyze the joint significance of the model, considering that for $\mathrm{H} 0$ all parameters are zero, and $\mathrm{H} 1$ for at least one parameter other than zero (FAVERO et al., 2014). The results indicate a p-value less than 0.0001 rejecting the null hypothesis of the likelihood ratio test, and therefore, there is at least one explanatory variable whose parameter has significance in the logistic model.

The results presented by the regression show that for at least one parameter other than zero (chi2 $=0.0000$ ). Regarding the quality of the model, we can see a pseudo R2 of 0.4374 which shows how the model explains the dependent variable. According to Fávero et al. (2014), the pseudo McFadden R2 is mostly used in logistic models to assess the fit when compared to other models.

Individual significance of the variables is evaluated by the $\mathrm{Z}$ test which operates similarly to the logistic regression t test (FÁVERO et al., 2014). In the 5\% significance level, 
the estimation process color / race $($ Cry $\mathrm{p}=0.619)$, Nationality $(\mathrm{Ny} p=0.664)$ and Degree of Instruction are not corroborated (see Table 8).

Table 8 - Logistic regression

\begin{tabular}{ccccccc}
\hline Variable & Coef. & Std. error & $\mathbf{Z}$ & $\mathbf{p}>|\mathbf{z}|$ & \multicolumn{2}{c}{ [Interval 95\%. conf.] } \\
\hline LogAsset & 1,397865 & .0598664 & 7.82 & 0.000 & 1,2853 & 1,5203 \\
LogExp & 6,386313 & .2778489 & 42.62 & 0.000 & 5,8643 & 6,9548 \\
FPy &, 7630336 & .0523537 & -3.94 & 0.000 & 0,6670 & 0,8729 \\
Rey & 6,981501 & .4291824 & 31.61 & 0.000 & 6,1890 & 7,8755 \\
Ideoy & 1,956753 & .1346258 & 9.76 & 0.000 & 1,7099 & 2,2392 \\
Cry & 1,028605 & .0583094 & 0.50 & 0.619 & 0,9204 & 1,1495 \\
Ny & 1,165168 & .4100618 & 0.43 & 0.664 & 0,5846 & 2,3225 \\
Ecy & 1,195382 & .0675913 & 3.16 & 0.002 & 1,0700 & 1,3355 \\
GIy & 1,127379 & .0743407 & 1.82 & 0.069 & 0,9907 & 1,2829 \\
Age &, 9636544 & .0023323 & -15.30 & 0.000 & 0,9591 & 0,9682 \\
\hline
\end{tabular}

Source: elaborated by the authors.

From the 5\% significance level of individual variables, we used the same significance parameter Wald $\mathrm{z}$ test from which the explanatory variable is excluded from the final model, and tested to verify the overall adequacy of the complete model.

The likelihood ratio test through lrtest command with Prob $>$ chi2 $=0.2271$, indicated that the estimation of the final model to the exclusion of the variables race (Cry), Nationality (Ny) and Instruction level (GIy) did not change the quality setting, making the model calculated by Stepwise model is preferable to the complete model estimated with all the explanatory variables.

Campaign expenditure variables (logExp) and goods (logAssets) have p-value $<0.05$ and positive coefficients demonstrating support the empirical proposition that campaign and Heritage expenses have positive relationship with the electoral success, with coefficients respectively 6,386 and 1,397, and other personal characteristics of the candidate and party.

From the analysis of the behavior of the explanatory variables and their respective estimated signals, it is clear that the amount of appropriate expenditure and the amount of the applicant's goods positively influence the electoral success as well as a different nationality Brazilian born, married civil state and the condition to be seeking re-election. Otherwise, negatively influence the electoral success the female characteristics and the candidate's age.

Starting from outputs regression, it is possible to describe the final expression estimated probability that a candidate is chosen as follows: 


$$
p_{i}=\frac{1}{1+e^{-\left(5,62 e-06+6,38 . \log \text { Exp }_{i}+0,140 . \log \text { Assets }_{i}+6,98 . \text { REy }_{i}+0,763 . \text { FPy }_{i}+1,95 . \text { Ideoy }_{i}+1,15 . \text { Ecy }_{i}+0,963 . \text { Age }_{i}\right)}}(1)
$$

The logistic regression model also allows you to identify the chance of occurrence of event of interest to the change in one unit the corresponding explanatory variable through the logistic command (FÁVERO; BELFIORE, 2017). The amount applied to the drive of interest is evidenced by the odds ratios for each explanatory variable, highlighted in Table 9.

Table 9 - Odds ratio and p-value

\begin{tabular}{ccc}
\hline Variable & Coef. & $\mathbf{p}>|\mathbf{z}|$ \\
\hline LogAsset & 1,397865 & 0.000 \\
LogExp & 6,386313 & 0.000 \\
FPy &, 7630336 & 0.000 \\
Rey & 6,981501 & 0.000 \\
Ideoy & 1,956753 & 0.000 \\
Cry & 1,028605 & 0.619 \\
Ny & 1,165168 & 0.664 \\
Ecy & 1,195382 & 0.002 \\
GIy & 1,127379 & 0.069 \\
Age &, 9636544 & 0.000
\end{tabular}

Source: elaborated by the authors.

From the odds ratio values shown, it is possible to indicate, by multiplying the incremental drive at variable coefficient corresponding odds ratio (FÁVERO; BELFIORE, 2017). For example, a candidate for each incremental year your age, multiply your chance of 0.963 , ie every year older reduces your chance to be elected. From this perspective, the most significant variable is to have candidate status, while the variables age and gender, because they have lower values than 1 , just showing that reduce the chances that corresponds to the previous finding that these are factors that negatively influence the chance of success in the election campaign.

The analysis sensitivity, specificity and model accuracy percentage is another way to assess a logistic model in the model classification table (FAVERO et al., 2014). The sensitivity indicates the successes considering only the observations that were in fact event. The model analyzed 24,759 valid observations, and managed to sort only 1547 individuals elected 3179 , representing $48.66 \%$ of the total hits.

Specificity relates to the percentage of success considering only the observations that were not event (FÁVERO; BELFIORE, 2017). In the present case indicates 20,825 unelected between 21,580 unelected candidates, representing $96.50 \%$. Considering both situations, the 
logistic model correctly classified instances and not occurrences in relation to number of observations a percentage of $90.36 \%$.

The standard model with a cutoff of 0.50 can more accurately predict the no events than the events. To better balance between sensitivity and specificity, it is necessary to change the cutting point. The statistical relationship between sensitivity, specificity and cutoff (cutoff) can be displayed graphically for better understanding of the necessary adjustments (FÁVERO et al., 2014). The analysis of the graph allows visualization of the curves to identify what would be a new and appropriate cutoff point for what is intended in the operative analysis.

Figure 2 -Sensitivity and probability cutoff

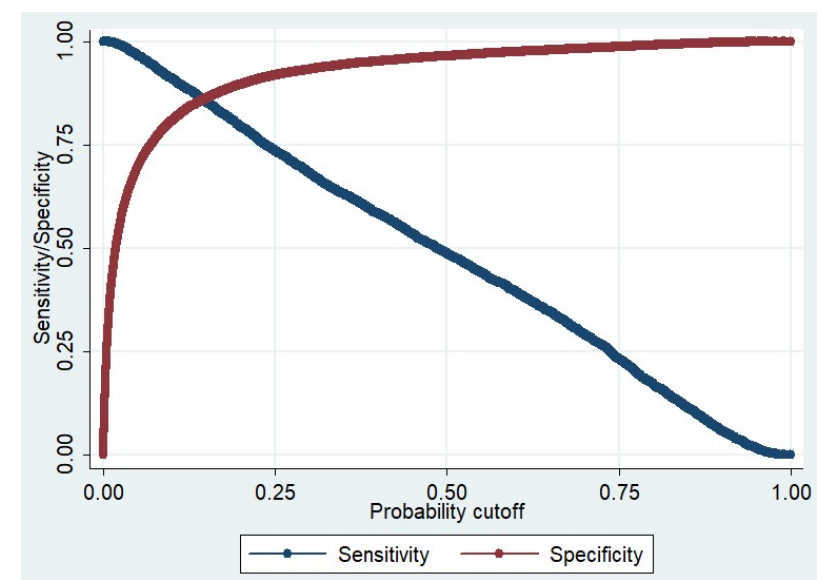

Source: elaborated by the authors.

To significantly increase the sensitivity, or ability to successfully hits, and the graphical display of a cut point corresponding to the intersection of the curves approximate shear $0.1(10 \%)$, which while reducing the power sensitivity, can weigh the qualities.

Table 10 - Adjustment Sensitivity and Specificity, with cutoffs 0.5 and 0.1

\begin{tabular}{|c|c|c|c|c|c|c|c|}
\hline \multirow{2}{*}{\multicolumn{2}{|c|}{ Ranking }} & \multicolumn{3}{|c|}{ Cutoff 0.5} & \multicolumn{3}{|c|}{ Cutoff 0.1} \\
\hline & & D & -D & Total & D & -D & Total \\
\hline+ & & 1547 & 755 & 2302 & 2894 & 4120 & 7014 \\
\hline- & & 1632 & 20825 & 22457 & 285 & 17460 & 17745 \\
\hline Total & & 3179 & 21580 & 24759 & 3179 & 21580 & 24759 \\
\hline Sensitivity & $\operatorname{Pr}(+\mid \mathrm{D})$ & & 48,66 & & & 91,03 & \\
\hline Specificity & $\operatorname{Pr}(-\mid \sim D$ & & 96,50 & & & 80,91 & \\
\hline Positive predictive value & $\operatorname{Pr}(\mathrm{D} \mid+)$ & & 67,20 & & & 41,26 & \\
\hline Predictive negative value & $\operatorname{Pr}(\mathrm{D} \sim \mid-)$ & & 92,73 & & & 98,39 & \\
\hline To-false $+\mathrm{d}$ & $\operatorname{Pr}(+\mid \sim D)$ & & 3,50 & & & 19,09 & \\
\hline False - for d & $\operatorname{Pr}(-\mid D)$ & & 51,34 & & & 8,97 & \\
\hline False ++ for classification & $\operatorname{Pr}(\mathrm{D} \sim \mid+)$ & & 32,80 & & & 58,74 & \\
\hline False ++ for classification & $\operatorname{Pr}(\mathrm{D} \mid-)$ & & 7,27 & & & 1,61 & \\
\hline Proper classification & & & 90,36 & & & 82,21 & \\
\hline
\end{tabular}

Source: elaborated by the authors. 
From a cut of $0.1(10 \%)$ can be achieved arrangements for 2302 candidates got success, a percentage of $91,03 \%$ of the elect. Regarding specificity, failure hits were reduced to 17460 , the 21,580 candidates who do not get success, less precision than in the general model. Considering both situations, the logistic model correctly classified instances and not occurrences in relation to number of observations, a percentage of $82,21 \%$, lower than the $90.36 \%$ of the standard application 0.5 .

The scope for reducing the cutoff, depends on the decision of what to who proposes to apply the regression model, and that scope would be interesting to the ROC curve (FÁVERO; BELFIORE, 2017).

The ROC curve (Receiver Operating Characteristic') is a measure that shows the model's ability to discriminate the categories of the dependent variable, whose established metrics indicate that the area under the curve less than or equal to 0.5 results from model can't discriminate categories, whereas with values above 0.8 indicate that the model has excellent discriminatory power (FÁVERO et al., 2014). In the range between 0.5 and 0.8 , discriminatory power is allocated just acceptable.

\section{Figure 3 - The ROC curve}

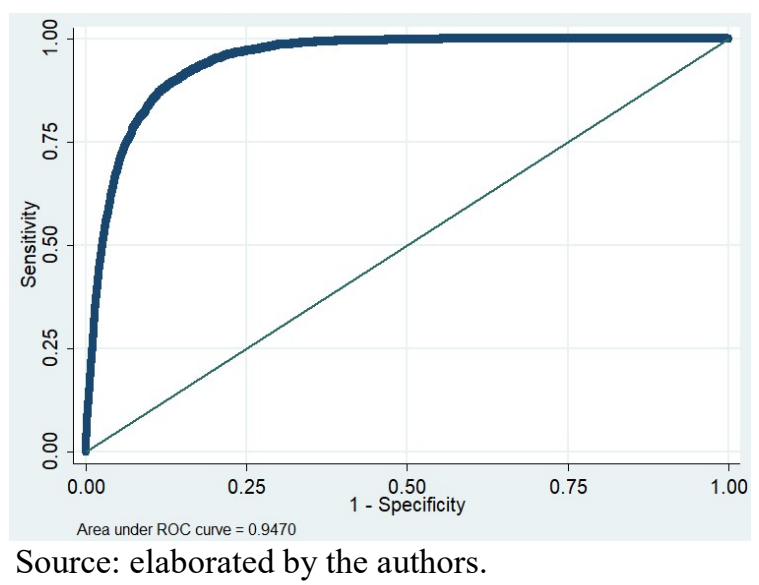

The results indicate that the area under the ROC curve is 0.95 , within the excellence parameter (0.8), indicating that the explanatory power of the model is good. Fávero and Belfiore (2017) point out that situations with these parameters have high overall efficiency and statistically significant explanatory variables to compose the expressions of occurrence probabilities of the event and not the event, which may indicate the need for inclusion of new explanatory variables in order to improve the character of predictability to predict the elect.

The logistic regression model assumes a value of 1 or 0 , the predicted probability is greater than 0.5 is scored as 1 , and the lower ranked 0; also why, Gujarati (2006, p. 488) points out that in models with returning torque, goodness of fit is of secondary importance. 
What matters are the signs of the expected regression coefficients and their statistical significance and practice.

In order to complement the analyzes, new regressions were established with the categories of parties and geographic regions, which allowed to identify some regions as well as a group of political parties that in the model have demonstrated significant in the success of their candidates.

Table 11 - Aditional Logistic regression

\begin{tabular}{cccc}
\hline Resy & Odds Ratio & $\mathbf{Z}$ & $\mathbf{P}>|\mathbf{z}|$ \\
\hline LogBens & 1,180717 & 4,02 & 0,000 \\
LogDesp & 7,63970 & 43,23 & 0,000 \\
FPy & 0,89726 & $-1,46$ & 0,144 \\
Rey & 6,17747 & 29,74 & 0,000 \\
Ideoy & 1,62115 & 6,50 & 0,000 \\
PAR_4 [MDB] & 0,39290 & $-3,01$ & 0,003 \\
PAR_7 [PC do B] & 0,43493 & $-2,55$ & 0,011 \\
PAR_16 [PODE] & 0,41882 & $-2,36$ & 0,018 \\
PAR_28 [PSDB] & 0,51291 & $-2,24$ & 0,025 \\
PAR_30 [PSL] & 0,25126 & 3,03 & 0,002 \\
PAR_33 [PT] & 0,55605 & $-1,99$ & 0,047 \\
PAR_40 [SD] & 0,41021 & $-2,36$ & 0,018 \\
Reg_2 [N] & 1,97189 & 6,92 & 0,000 \\
Reg_3 [NE] & 2,35633 & 9,56 & 0,000 \\
Reg_4 [Sul] & 1,45816 & 3,77 & 0,000 \\
\hline Source: elaborated by the authors. & &
\end{tabular}

Source: elaborated by the authors.

It is interesting to note that in the presence of parties and geographic regions, the private financing variable is no longer significant in the model.

\section{DATA ANALYSIS AND RESULTS DISCUSSION}

The relevant point of discussion is the analysis of the impact of financial variables in relation to the candidate's impact be elected. At this point it is important to consider the odds ratio of occurrence of the event (success) in terms of odds ratio (FÁVERO et al., 2014) to change by one explanatory variable.

The regression empirical logistic model resulted after processing the data in a model with significant variables whose coefficients have successful relationship or failure in the election campaign. The financial variables were identified with positive relation to success, ie 
greater amount of campaign by the candidate and greater equity candidate's availability expenditures are related to larger candidate's chances to be elected, confirming the theoretical hypothesis that the economic power influence the election result.

The analysis of the main variable of interest, economic power, showed influence on electoral success in the three sub-hypotheses at a level of $95 \%$ significance. The biggest influence on the electoral result is the amount of electoral expenses invested in the electoral campaign, at a rate of $6,386(\mathrm{p}=.0000)$ and property ownership (Coef. 1,397 $\mathrm{p}=.0000)$, corroborating the theoretical propositions (ARVATE; BIDERMAN, 2005, ARVATE, AVELINO， LUCINDA， 2008， CERVI，2010， SALLABERRY， RODRIGUES, VENDRUSCOLO, 2014).

The variable indicative of empirically tested entrepreneurial financing also showed an influence, however, on the odds ratio (FEy Coef. $0.763 \mathrm{p}=.0000$ ) divergent from that expected. This divergence may be due to several factors, including the interest groups involved with the candidates (MANIN; PRZEWORSKI; STOKES, 2006) at times of political turmoil. Another possibility is that the financial resources of organizations are enough to skew the entire electoral process, including resulting in contradictory choices.

The analysis of the results of the hypotheses indicative of political-partisan and ideological relations demonstrates a positive influence on electoral success, in which case the re-election condition indicates greater influence (Coef 6,981 $\mathrm{p}=.0000$ ) among all known variables, and even the proposal empirical ideology (Coef. 1,956 p =.0000) signals the influence on the electoral outcome for those candidates in parties of the winning national coalition.

The results of the complementary analyzes showed that in the proposed model, by dividing the geographic regions and the parties, it is possible to identify a number of parties that are capable of influencing electoral success in an inverse way, that is, their candidates have a lower probability of obtaining (Coef., $392 \mathrm{p}=.003$ ), PT (Coef., $556 \mathrm{p}=.047$ ), PSDB (Coef., $513 \mathrm{p}=.025)$, PC of the B (Coef., $435 \mathrm{p}=.011$ ), CAN (Coef., $419 \mathrm{p}=.018$ ), PSL (Coef., $251 \mathrm{p}=.002$ ), and SD (Coef., $410 \mathrm{p}=.018$ ), while the regions that showed greater significance in the model positively influencing candidates from the northeast at $135 \%$ and from the north by $97 \%$ more chances (Coef. $2,356 p=.0000$ and Coef. $1,972 p=.0000$ ) than the reference candidates, from the Midwest.

By validating the reelection condition with a positive influence on electoral success, we corroborate the dominant literature (AVIS, FINAN, VARJÃO, 2018, COELHO, 2004, CAVALCANTE, 2015, KLEIN, SAKURAI, 2015) his previous work, for having a superior 
economic condition, and the public machine at his disposal. The positive relation of the dominant ideology reflects collective social behaviors, on the condition that they are positively influenced candidates of parties with coalition with the president-elect, therefore denominated like dominant ideology, validated by the election of the president. Still positive, this variable is hampered by the fact that in the states coalitions are carried out between parties with different national alignments.

The candidate's condition seeks re-election is the factor most related to the reason for the electoral chances of success, expanding at 6 times the chances of a candidate to succeed in the election. Although it has decreased the amount of re-elected, this process characteristic remains, possibly by the applicant of the fact be known prior approval of the voter, the longer exposure in the media arising from the previous term of office.

In summary, the hypotheses of interest demonstrated the behavior presented in the following table, compared to expectations and confirmation of hypotheses.

Table 12 - Hypothesis results

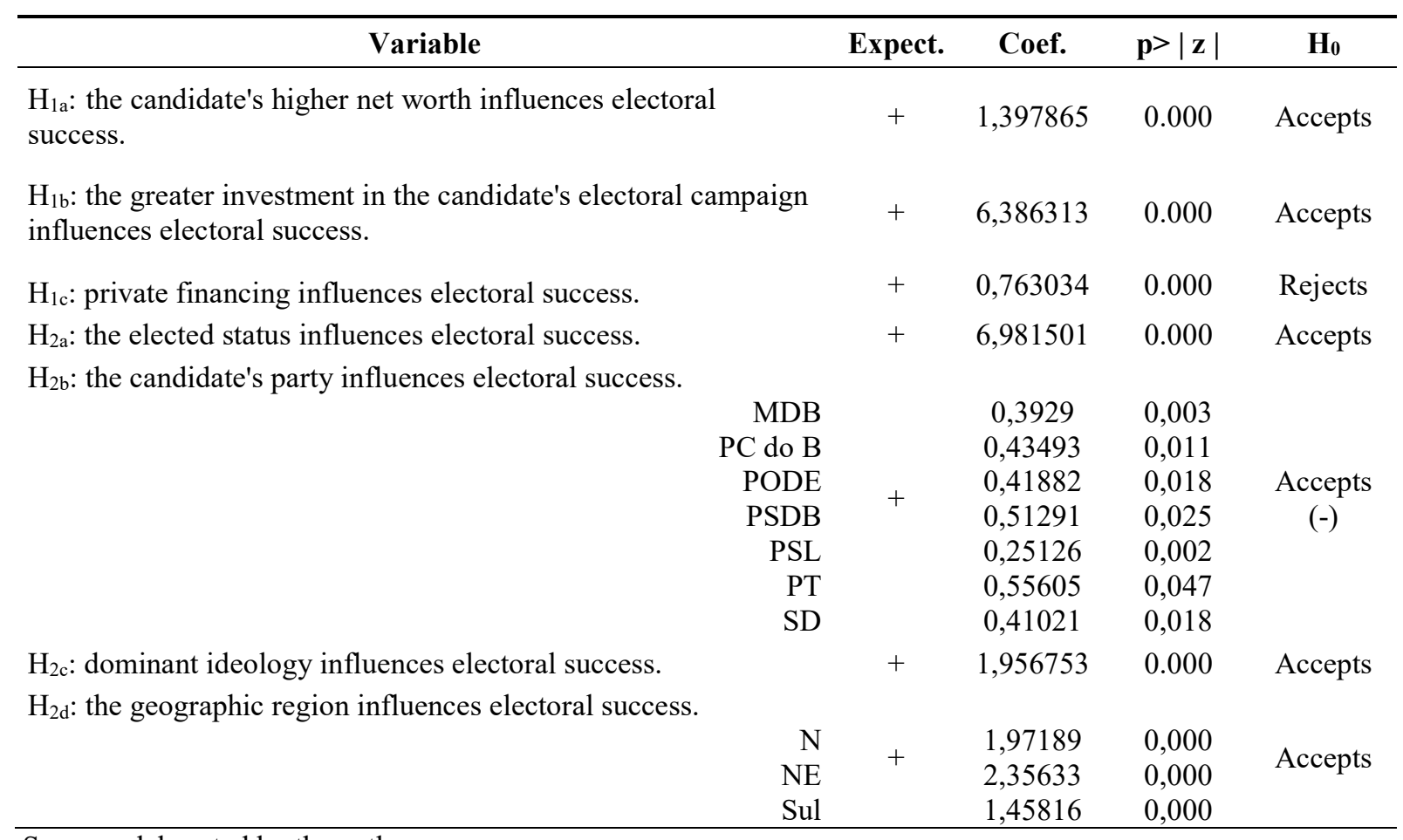

Source: elaborated by the authors.

Some variables of control by the personal characteristics of the candidates also showed a correlation with the electoral success, among them the Marital Status of the Candidate and the Age. The Marital State where the married candidates have higher odds ratio of being elected (ECy Coef. 1,195 p=.002) than candidates unmarried, separated, divorced and widowed, as expected in the hypothesis proposed that married people they are 
more aligned to features common to traditional family. Possibly because of this impression of the paternalistic family.

The age variable was the other one that showed statistical significance, indicating that for each additional year the odds ratio decreases by 3.6\% (EC and Coef., $964 \mathrm{p}=.000$ ). This variable demonstrates a distinct characteristic than expected, since older candidates have more time to show their qualities, develop networks, and even capture variance of reelections. Other control variables did not show statistical significance, such as color and race groups, nationality and gender, and last, with a small margin of the cut line, in the present study sample.

\section{FINAL CONSIDERATIONS}

Regarding contribution to the development of an electoral prediction model based on financial variables, the model correlated significantly with ability to demonstrate greater respect to $43,7 \%$ of the election result. The variables demonstrated that the magnitude of the applicant's goods and campaign spending are significant variables, with a positive sign. This evidence demonstrates the linkage of economic power, or financial availability, positively influence the electoral sucess.

The corporate financing variable presented results that diverge significantly from the expected meaning, indicating a lower probability of electoral success. However, it is possible to be a sign that such corporate financing impairs a rational process of choice, including limiting the explanatory power of model. As of the next election, it is necessary to broaden the sample of the research, including for previous years, which have had business financing, in order to seek a better understanding of the phenomenon.

Evidence of the success of political-partisan and ideological relations demonstrates positive influence as reelection, dominant ideology and geographic region as expected, although in the scope of party bonding the sign presented is inversely as expected for traditional parties.

Further analysis showed that other candidates profile aspects are related to the election result, among which are positively related to the common empirical model, as the variables of marital status with positive influence and the age, in an opposite direction than expected, indicating that in the last elections voters prioritized younger candidates, although there was a positive appreciation of previous experience in the position. 
The model fit demonstrated high specificity capacity (not predict events) and sensitivity (to predict events) adjusted to decrease from the cutting. For these characteristics and explanatory power curve, it evidenced the possibility of including new variables to improve the election forecast, which does not differ from initial exploratory proposal.

The research limitations and the possibility of including other variables, demonstrate the importance of deepening the study of the subject, including in relation to the dependent variable whose categories in practice depend on different electoral quantitative results. Suggestions for continuity of research indicate the importance of including other variables in the model, such as the variable depending on the number of votes, and among the explanatory variables, participation in the partisan fund, as well as the deepening of the theoretical discussion of the evidences found outside the scope of present research.

\section{REFERENCES}

ARAÚJO JÚNIOR, Ari F.; CANÇADO, Paulo L.; SHIKIDA, Cláudio D. Economics and politics: o que determina as chances de reeleição em municípios? O caso das eleições municipais de Minas Gerais de 2000. Informe Gepec, v. 9, n. 2, p. 1-19, 2005.

ARVATE, Paulo R.; AVELINO, George; LUCINDA, Claudio R. Existe influência da ideologia sobre o resultado fiscal dos governos estaduais brasileiros? Estudos Econômicos, São Paulo, v. 38, n. 4, p. 789-814, 2008.

ARVATE, Paulo R.; BIDERMAN, Ciro. Economia do setor público do Brasil. Rio de Janeiro: Elsevier, 2005.

AVIS, Eric; FERRAZ, Claudio A. F.; FINAN, Frederico; VARJÃO, Carlos. Money and Politics: The Effects of Campaign Spending Limits on Political Entry and Competition. NBER Working Paper, n. 23508, 2018.

BAINES, Paul R.; EGAN, John. Marketing and political campaigning: mutually exclusive or exclusively mutual? Qualitative Market Research, v. 4, n. 1, p. 25-34, 2001.

BARROS, Denise F.; SAUERBRONN, João F. R.; AYROSA, E. A. T. Representações do eleitor: revendo teorias e propondo novos caminhos. Revista de Administração Pública, v. 46, n. 2, p. 477-491, 2012.

BRENDER, Adi; DRAZEN, Allan. Political budget cycles in new versus established democracies. Journal of Monetary Economics, v. 52, n. 7, p. 1271-1295, 2005.

CAVALCANTE, Pedro. Vale a pena ser um bom prefeito? Comportamento eleitoral e reeleição no Brasil. Opinião Pública, v. 21, n. 1, p. 87-104, 2015. 
CAZZOLATO, N. K.; CANDIDO, J. G. O caminho das verbas público-partidárias e o custo do voto. Revista Eletrônica Gestão e Serviços, v. 4, n. 2, p. 678-699, 2013.

CERVI, Emerson U. Financiamento de campanha e desempenho eleitoral no Brasil: análise das contribuições de pessoas jurídicas, físicas e partidos políticos às eleições de 2008 nas capitais de estado. Revista Brasileira de Ciência Política, n. 4, p. 135-167, 2010.

COELHO, César A. C. Ciclos político econômicos e o poder local. 2004. 143 f. Dissertação (mestrado em economia) - Escola de Economia e Gestão, Universidade do Minho, Minho, 2004.

CRUZ, Paula Y. G.; PARENTE, Paulo H. N. Desempenho e Conexão Política no Brasil: Uma Análise a Partir das Eleições de 2014 NAVUS - Revista de Gestão e Tecnologia, v. 8, n. 3, p. 8-22, 2018. DOI: http://dx.doi.org/10.22279/navus.2018.

DIAS, Bruno P.; NOSSA, Valcemiro; MONTE-MOR, Danilo S. O investimento público influencia na reeleição? Um estudo empírico nos municípios do estado do Espírito Santo.

Revista de Administração Pública, Rio de Janeiro, v. 52, n. 5,p. 880-898, out. 2018. DOI: http://dx.doi.org/10.1590/0034-7612172594

DOWNS, Anthony N. An economic theory of political action in a democracy. Journal of Political Economy, Chicago, v. 65, n. 2, p. 135-150, 1957.

DRAZEN, Allan; ESLAVA, Marcela. Electoral manipulation via expenditure composition: theory and evidence. NBER Working Paper, n. 11085, 2005.

FÁVERO, Luís P., BELFIORE, Patrícia., TAKAMATSU, R. T., SUZART, J. Métodos quantitativos com Stata. Elselvier, 1a edição. Rio de Janeiro-RJ, 131-142, 2014. FÁVERO, L. P.; BELFIORE, P. Manual de análise de dados. Rio de Janeiro, Elsevier, 2017.

FERNANDES, I. F. A. L.; FERNANDES, G. A. A. L. A Importância do Crescimento Econômico Local na Escolha do Chefe do Executivo no Brasil. Revista de Administração Pública, v. 51, n. 4, p. 653-688, 2017. DOI: http://dx.doi.org/10.1590/0034-7612146091 FIELD, A. Descobrindo a estatística usando o SPSS. Bookman Editora, 2009.

GIL, A. C. Métodos e técnicas de pesquisa social. São Paulo: Atlas, 1999.

GRANDI, Rodolfo; MARINS, Alexandre; FALCÃO, Eduardo (Org.). Voto é marketing... o resto é política. São Paulo: Edições Loyola, 1992.

GUJARATI, D. N. Econometria Básica. Rio de Janeiro, Elsevier, 2006.

HAIR, J. F.; BLACK, W. C.; BABIN, B. J.; ANDERSON, R. E.; TATHAM, R. L. Análise multivariada de dados. Bookman Editora, 2009. 
HORTA, C. J. G.; DUFLOTH, S. C.; FREITAS, D. R. R. Características socioeconômicas da população e de seus representantes eleitos nas assembleias legislativas brasileiras: análise de convergência entre perfis. Revista do Serviço Público, v. 67, n. 4, p. 525-554, 2016.

HOSMER, D. W.; LEMESHOW, S. Applied logistic regression, Wiley. New York, 1989. KAMAKURA, Wagner A. Using Voter-choice Modeling to Plan Final Campaigns in Runoff Elections. Revista de Administração Contemporânea, v. 20, n. 6, p. 753-776, 2016. DOI: http://dx.doi.org/10.1590/1982-7849rac2016160116 KLEIN, Fabio. Reelection incentives and political budget cycle: evidence from Brazil.

Revista de Administração Pública, Rio de Janeiro, v. 44, n. 2, p. 283-337, 2010.

KLEIN, Fabio; SAKURAI, Sergio N. Term limits and political budget cycles at the local level: evidence from a young democracy. European Journal of Political Economy, v. 37, p. 21-36, 2015.

MANIN, Bernard; PRZEWORSKI, Adam; STOKES, Susan C. Eleições e representação.

Lua Nova - Revista de Cultura e Política, n. 67, p. 105-138, 2006.

MORAES, Rubens L.; ANDION, Carolina; PINHO, Josiani L. Cartografia das Controvérsias na Arena Pública da Corrupção Eleitoral no Brasil. Cadernos EBAPE.BR, v. 15, n. 4, p. 846-876, 2017. DOI: http://dx.doi.org/10.1590/1679-395154831

NAKAGUMA, Marcus Y.; BENDER, Siegfried. Mudança institucional e política fiscal no Brasil: uma avaliação da experiência recente. Brasília: Esaf, 2005.

NICOLAU, Jairo. O sistema eleitoral de lista aberta no Brasil. DADOS-Revista de ciências sociais, v. 49, n. 4, 2006.

O'SHAUGNNESSY, Nicholas. The marketing of political marketing. European Journal of Marketing, v. 35, n. 9/10, p. 1047-1057, 2001.

PELTZMAN, Sam. Voters as fiscal conservatives. Quarterly Journal of Economics, v. 107, n. 2, p. 327-261, 1992.

PINHEIRO, Bruno G.; DE LUCA, Márcia M. M; VASCONCELOS, Alessandra C. de. CONEXÕES POLÍTICAS NAS MAIORES COMPANHIAS LISTADAS NA

BM\&FBOVESPA. Revista Eletrônica de Administração, v. 22, n. 2, p. 394-418, 2016. RODRIGUES, Luis F.; SALLABERRY, Jonatas. D. Aspectos legais e contábeis da prestação de contas eleitorais para as eleições de 2012: uma análise empírica à luz da legislação vigente. Revista Brasileira de Contabilidade, vol. 199, p. 61-75, 2013. SALLABERRY, Jonatas D.; VENDRUSCOLO, Maria. I.; RODRIGUES, Luis. F. Receitas Eleitorais: da Teoria Contábil à Prática. ConTexto, v. 14, n. 26, 2014. 
SCHUKNECHT, Ludger. Political business cycles in developing countries. Kyklos, v. 49, n. 2, p. 155-70, 1996.

SHI, Min; SVENSSON, Jakob. Political budget cycles: do they differ across countries and why? Journal of Public Economics, v. 90, n. 8-9, p. 1367-1389, 2006.

STOKES, Susan C. Public opinion and market reforms: the limits of economic voting.

Comparative Political Studies, v. 29, p 499-519, 1996.

VICENTE, Ernesto F. R.; NASCIMENTO, Leonardo S. do. A efetividade dos ciclos políticos nos municípios brasileiros: um enfoque contábil. Revista de Contabilidade e Organizações, v. 6, n. 14, p. 106-126, 2012.

WALLIMAN, Nicholas. Your research project: a step-by-step guide for the first-time researcher. Sage, 2005.

ZHU, Hongjin; CHUNG, Chi-Nien. Portfolios of political ties and business group strategy in emerging economies: Evidence from Taiwan. Administrative Science Quarterly, v. 59, n. 4, p. 599-638, 2014. 